\title{
ICARIAN COMMUNISM BETWEEN 1841 AND 1848: A COMMUNITY OF READERS
}

\author{
FRANÇOIS FOURN
}

\begin{abstract}
In 1842, readers of Populaire, a journal founded a year earlier by Etienne Cabet, named themselves the Icarian communists. But what was this entity? Was it a party, a communist one, a school of socialism, a network, a movement, a sect? All these words could be used to describe the nature of their bonds which had been developed between 1841 and 1848. Nevertheless, we propose an additional name - a community of readers - for the new, exclusive form of existing together that was invented. These readers not only read but produced texts addressed to other members of the community with whom they also shared money, egalitarian convictions, faith in fraternity, their gratitude and even devotion to Cabet. Belonging to this community engaged the entirety of its members' lives and developed and affirmed itself in diverse forms. It also involved often painful lessons about a community's limits, both internal and with respect to the rest of French society, which could barely tolerate its existence.
\end{abstract}

Keywords: community, Icarian communism, utopian socialism, readers of journals, France, 1848 
At the beginning of 1840, former deputy and general prosecutor Etienne Cabet published a communist manifesto entitled Travels in Icaria. His intention was to put a complete reconstruction of the modern industrial world on the agenda, civilising and rebuilding the entire nineteenth century on the basis of equality, fraternity, justice and community. In March 1841, Cabet and the first followers of his doctrine (exclusively workers) inaugurated Populaire de 1841, journal de réorganisation sociale et politique 1 in order to gather the working masses around his project. It started as a monthly periodical and became a weekly one. In September 1842, the shareholders of the journal univocally decided to apply the name Icarian communists to all those adhering to and recognizing themselves in Cabet's project. The project endorsed communitarian ideas and promoted economic, cultural and political progress by means of "education and moralisation of the people" without resorting to violence or the help of any secret societies. Followers were neither revolutionaries nor materialists. For instance, they challenged the radical postulates of Humanitaire, which called for the abolition of the family, and rejected the communitarian ideal of free and diverse thinking espoused by Richard Lahautière in his journal Fraternitê2. In fact, it was in order to clearly distinguish themselves from all the other tendencies of nascent communism that Cabet's readers had chosen to be called Icarians. Starting with 1500 subscribers, their numbers grew sizably to 3000 by 1845 and 5000 by early $1847^{3}$. Through the issuance of coupons and shares, they collected over 12,500 francs during this period and over 50,000 francs by February 1948, thus providing resources for their journal, brochures and further publicity. Despite the data available, it is still difficult to estimate the number of readers who had indeed engaged with the movement. Since many were impoverished workers, who likely combined their funds with a comrade or two or many more to afford the subscription, pay ten francs for a coupon or buy a share in Populaire. Each copy was read more than once and often aloud, particularly where workers would gather: workshops, soup stalls, courtyards, nearby forests, in the evenings or on summer Sundays. Their activism took diverse shapes, from common walks and picnics in the village to singing parties and implementation of more concrete forms of help such as fundraising for striking

\footnotetext{
${ }^{1}$ Named so to be distinguished from another, older and openly republican journal - Populaire, journal of the political, material and moral interests of the People, which Cabet had directed in 1833 and 1834, before being condemned to five years of exile for two articles published in this newspaper about the Polish refugees that the regime of Louis-Philippe had refused to welcome in France.

${ }^{2}$ For L'Humanitaire see: Paris 2014. For La Fraternité of Lahautière, that of 1841 and that of 1845, see: Maillard 1999; Maillard 2015.

${ }^{3}$ For comparison, the Démocratie Pacifique, the Fourierist newspaper launched in 1843 and directed by Victor Considerant used to be published in 2200 copies, however true is also that it was issued daily; see Beecher 2012, 151. For a very precise source on the circulation of newspapers in France in 1845, see the box of the National Archives BB17 a145, folder 1 - a register carried out by the State services responsible for collecting the tax on stamps and periodicals. According to this document, the Fraternité of Lahautière printed 1589 copies on average and Atelier, another newspaper comparable to Populaire, 705 copies. The major republican newspapers, the National and the Réforme printed respectively 4017 and 1696; see Francois Fourn, Etienne Cabet (1788-1856). Une propagande républicaine, Villeneuve d'Asq, Presses du Septentrion, 1998, vol. II, p. 573.
} 
comrades. The Almanach Icarien, issued once a year and surely read in a less collective manner, had a print run of 8000 copies in 1843, and 10,000 copies in 1848 .

Network, movement, party, school, sect, association - all these words could be used to describe the gathering of Cabet's disciples, at least until February 3, 1848, when an avant-garde of Icarian pioneers left the port of Le Havre to found an experimental colony, a real commune in America.

Speaking juridically, before setting off, the Icarians were members in a limited liability partnership connected by the shares they held, and the journal they owned. They joined a party, a communist one, the very word used by Cabet himself as early as 1841: "Of all the parties," he wrote, "it is the communist one which most ardently aspires to destroy the competition, the rivalry, the antagonism and to establish order, concentration and unity; it is the communist party, therefore, which to the highest degree should be disposed to pursue a singular direction, even more before than after founding the Community" (Cabet 1841, 40). Between 1841 and 1842 the author of Travels in Icaria fought with all the alternative theories of communism that were competing in the workers' milieus of Paris and Lyon. He stigmatised them as the new Hébertists or Babouvists, ready to compromise everything with their impatience and imprudence.

Thus emerged a network resulting from Cabet's role at the heart of a system of epistolary bonds, interwoven between him and his readers (Fourn 1998, 571-642; Fourn 2014, 95-118), a system consisting of multiple circles, with its centre situated in the bureaux of Populaire on Jean-Jacques Rousseau's street in Paris, the location of reunions and the archive for militant writings. However, secondary centres were scattered all over France in places where Icarians were slowly gaining popularity: first in Lyon, followed by Vienne in the department of Isère, Givors, Rive-de-Gier, Saint-Etienne, Nantes, Niort in Deux-Sèvres, Perpignan, Marseille, Toulouse, Agen, Cahors in the South, Mirecourt, Vosges, Saint-Quentin in Aisne, Reims, Alger... Everywhere, in all the departments of France, and even as far as Barcelona and London, Cabet nominated one or more correspondents, sometimes a whole commission, to direct, animate and guide in his name the groups of men and women converted to his conception of communism (Tristan 1980) ${ }^{4}$. Correspondents were chosen for the zeal of their proselytism, solidity of their legalist and pacifist convictions and capacity to develop local influences. They engaged their reputations, tranquility, money, and much of their time in order to circulate, sell, read and publicly discuss Icarian writings, articles published in Populaire since March 1841 and brochures printed by the dozen (Fourn 2003). Jacques Valette chose to use "network" (réseau) to designate all these Icarian and Fourierist interconnections in his study on "utopian networks in France" circa 1848 (Valette 1981, 87)5.

\footnotetext{
${ }^{4}$ In 1844, all the communist workers she had met during her journey, particularly in Lyon, were Icarians.

${ }^{5}$ For a comparative study of readerships of Démocratie Pacifique and Populaire, incl. maps, see: Robert 1999.
} 
Earlier in 1974, Christopher H. Johnson proposed to label Icarianism as a movement and subsequently sect. What was to demarcate these two usages was the publication in 1848 of $\mathrm{V}$ rai Christianisme suivant Jésus-Christ (Johnson 1974, 207-260; Title of chapter 5 reads: "From Movement to Sect, 1846-1847” ). Cabet himself wasn't particularly against the word sect although he preferred to speak about religion. Well before 1846, since the first issues of Populaire, early Christianity was mentioned as the model for the movement. Cabet called the supporters of his doctrines his disciples, explicitly referring to the early Christians and apostles. Authorities of the July monarchy dubbed him an influential and dangerous "leader of the sect" ${ }^{6}$. Neither did he hesitate to compare his destiny with that of Christ. However, Cabet preferred to identify Icarian communism with a school, since he accepted the idea of the coexistence of different currents of thought within French socialism in 1840. To underscore the relationship held for better or worse between the Icarians and Fourierists, Cabet chose the 'phalanstery school' (Fourn 1999).

In 1847, Cabet coined a new phrase: the big Icarian family ${ }^{8}$. The Icarians addressed themselves as brothers and sisters, expressing their unlimited admiration and recognition toward their much beloved and revered Father Cabet, who for his part didn't hesitate to call them his children. These words indicated the kind of bonds that linked the master with his disciples: they evoked an affection and distinct positions and functions, rather than a proper relationship of power. It is Cabet who serves his disciples and not the other way around. He offered his technical competences and devotion, dedicated his whole life to a cause which was not entirely his own and rather owes allegiance to the Icarian people, where he only partially belonged. In the nineteenth century, civilisation was often understood as a process in which community preceded proprietary society (Proudhon 1994) ${ }^{9}$. It was also accepted that in primitive stateless societies, the head man's function differed from that of a king or magistrate. In fact, he was deprived of power, authority, of any opportunity to issue orders, since there was no duty to obey him. He was a prestigious old man, an eloquent sage whom the people consulted only on their own initiative (Clastres 1974, 175-176). Within the tribe of Icarian communists, Cabet was

\footnotetext{
${ }^{6}$ For example, Gabriel Delessert, prefect of the Paris police, in a report from January 5, 1848 on the correspondence of Cabet, which has just been seized. See in National Archives, box BB18 1451, folder 3598. Besides, he drafts a list of all the already identified correspondents of Cabet and classifies them by departments.

${ }^{7}$ In July 1840, concerning the banquet of Belleville, Theodore Dezamy and Jean-Jacques Pillot, spoke of the "egalitarian school" to designate the communists who made themselves known for the first time under this name. See. J.-J. Pillot, Th. Dézamy, Dutilloy, Homberg, Premier banquet communiste, le 1er juillet 1840, Paris, 1840. In 1847, while the Populaire becomes a weekly magazine, Cabet writes: "The Communist School and the Populaire want to exercise all the rights that the law still assures the citizens, but they also want to limit themselves to what is legal and do all that will be possible to avoid the lawsuits". Populaire, 25 April, 1847, in the prospectus of the newspaper.

${ }^{8}$ Cabet, "Grande famille icarienne" in: Réalisation de la Communauté d'Icarie, 1847, p. 102

${ }^{9}$ It was Proudhon in 1840, for instance, who expressed such a view, at the end of his What is property?, see: Proudhon 1994.
} 
such a leader without power, an old republican who experienced exile for the sake of noble political motives.

In Travels in Icaria there is an imaginary community with Icarus as a leader without coercive power, who in fact renounces his leadership as quickly as he can. There was also a real community, resembling other American colonies, which survived from 1848 until 1898. As soon as Cabet tried to take command of it in 1856, he was expelled and the community decided to function without its founder. But, as we wish to emphasize, there was a third Icarian community, partly merged with the previous two. It was a community of Cabet's disciples from before their departure to the United States, a community of the readers of Populaire. In one of my earlier texts, I had already proposed imagining a community of readers (Fourn 2015, 203-216) comprised of subscribers and shareholders of the journal. The aim then was to write a history of Cabet's journal. Now, I would prefer to consider the correspondence of his readers as it was circulating between different groups of Icarians. In contrast to tendencies in French society of 1840 with its competition among individuals and its resulting misery, Icarians even before their departure to America, invented and experimented with forms of communal living, sharing convictions and values, money, the collective work of their proselytism, new forms of solidarity which were not just philosophical or political but engaged all aspects of their existence, original forms of coexistence in society - intimate, egalitarian, brotherly but without a doubt also exclusive $^{10}$.

\section{To be written, to be read: forms of communitarian belonging}

The community of Cabet's readers, this world of Icarians, at first glance seems quite homogeneous in that: its members adopted a very characteristic discursive register, using a utopian language; got excited about the same millenarianist declamations; shared a vision of the future that distinguished them from even enlightened men and women; devoted themselves to militant engagements with exceptional tenderness, friendliness and familiarity; displayed thea recognizable posture of zealots, persecuted but devoted; and on occasionally wore special uniforms (Fourn 2017). Nevertheless, the trajectories which led them to this community we are heterogenous: some were workers, often, but not always, belonging to the most qualified professions, some were truly impoverished, and some were bourgeois merchants, doctors, artists and lawyers. They came together with different aspirations, class ethics and cultural capacities. Veiled tensions, diffused misunderstandings, imperceptible ressentiments, unspoken deceptions, all instigated them to write (s'écrire), to explain themselves, to compete in demonstrations of their loyalty and devotion toward what united them, to attempt to grasp

${ }^{10}$ Regarding the opposition between society and community, see: Tönnies 2017. 
publicly what they shared and lived through together. All of them maintained a highly conflicted relationship with established society well before they decided to permanently leave for the other side of the Atlantic, beyond the world of oppression, hatred, despair and dehumanization. The communal assembly of readers of Populaire constituted the first form of their escape; they invented it as they wrote and enlivened their correspondence. This community was imprecise, incoherent, informal; it had not been conceptualized, created or consciously programmed by the shareholders themselves; it was not explicit. Spontaneous Utopia always in progress, was rather an experimental idea, a tool of perpetual invention (Lacroix 1974, 526-558). Before 1848, this world of Cabet's readers was an enclosed, isolated world, as they themselves sometimes lamented. Around them, opposing them, the whole of the democratic press spread indifference and ignorance, conspiring to keep everyone silent. When the Icarians wrote to Cabet asking him to publish their letters, they knew that fellow Icarians would be their only readers. The public space in which they were allowed to participate did not extend beyond their circle of co-religionists. Holding an Icarian publication in hand, reading it aloud to an audience of workers, revealed an intention to participate in this common space, being not so much a place of liberation of speech, as a stage to show oneself a perfect Icarian. Cabet's publications, the newspaper as well as the brochures, functioned to some extent as a social network whose purpose was to signify, for both the writer and the reader, a sense of belonging to a group of friends. One's entire life, including its professional, familial and affective aspects was engaged. In addition there was an intellectual education consisting of permanent exposure to anti-communist hatred. Correspondence addressed to Cabet constituted an essential part of the contents of Populaire as well as of his other works. It showed his disciples' good attitude and devotion towards him; their propensity to shed abundant tears both in happiness and suffering, whether learning the good news of their departure to Icaria, or undergoing so many persecutions from the hands of their superiors, the rich, proprietors, Catholic priests, the political police, the regime of Louis-Philippe...

Anne Buisson, a worker at a Lyon flower stall and one of the first adherents of the movement, introduced herself as a worker-singer. Her husband was a master painter and plasterer, an Icarian activist of first rank, one of the sixty-nine members of the first vanguard who left Le Havre to found Icaria in Texas in February $1848^{11}$. However, she was the one who converted him to communist ideas. A few years earlier, despite serious writing difficulties ${ }^{12}$, it was she who corresponded with Cabet, whom she called her "mentor". In September 1842, she asked permission to "publish her thoughts" and to establish a newspaper entitled Popular

\footnotetext{
11 See particularly his letter to Faucon, Cabet's correspondent in Lyon, sent from Icarie, le 2 June 1848, in: Populaire,

13 August 1848.

12 I’ve chosen to correct her very faulty spelling here.
} 
Gazette of Women or Dedicated to Women, which she wished to edit on her own. We do not know the response sent to her. In February 1844, after a stay in Ain, she wrote again to the director of Populaire: 'Dear citizen, the circulation of your works assure you of zealous defenders, and Belley, you must believe, will provide you with the truly zealous, the inhabitants of this little town and the surrounding area weep for joy when they are read about your communitarian organisation, everyone would like to have Travels in Icaria and all your other works of which they are entitled through your almanac of eighteen hundred forty-three of which they would like to all be possessors and with which they have become acquainted through only two copies that were circulated by a friend and one of your zealous subscribers.'. She requested that her letter be published in Populaire ${ }^{13}$.

There is also a story from 1847, regarding a young woman, an ardent activist from Toulon. Icarians from Var honored her memory ${ }^{14}$. In a letter they addressed to Cabet, and through him to all their co-religionists, they expressed the sadness that overwhelmed them after the death of their 'younger sister'. They described her exemplary commitment to the Icarian doctrine, 'whose purpose she had so fully understood'. They said, 'She was animated by a lively faith, acquired by reading the Travels in Icaria and Vrai Christianisme.'. A courageous militant, she opposed the anti-communist aversion and was imagining her emigration to Icaria 'to found the earthly paradise that will serve as an example for all people and to accomplish all that is humanly possible for those striving to realise the law of the Brotherhood'. As a teacher, she would have helped to convey the principles of morality and fraternity to a younger generations of settlers. Her case, like that of Anne Buisson, confirmed Cabet's thesis. He argued, in the last pages of his Voyage en Icarie, that women would be the most persuasive 'apostles' of his peaceful communism. If the statement of his communist system was written in the form of a novel, it was with an eye to its female readers ${ }^{15}$. The community of Cabet lecturers was feminized voluntarily. Women were invited among Icarians for their propensity for peaceful, familial, smiling and cheerful legalism, and not only as the wives of communist militants. Such importance given to women was unique among the readership of French newspapers of the 1840s, with the exception of the feminist press and the Démocratie pacifique, which had many female readers. The feminization of the Icarians' world increased between 1841 and 1848, in inverse proportion to the decreasing share of the poor and disturbing proletarians and in parallel with the more reassuring rise in the qualification levels of the militants. In their letter to Cabet, the Var correspondents depicted themselves with a ritual gravity. In collective, egalitarian and fraternal manner, they spoke of their way of doing things and of their 'religious

\footnotetext{
13 To be found in: Paris Historical Library, Cabet's Papers, manuscripts n¹052, folios 46 to 48.

14 Cabet, Réalisation d'Icarie, $\mathrm{n}^{\circ}$, December 1847, p. 391-392. Text signed by 107 Icariens, among whom 26 women.

15 Cabet, Vyage en Icarie, 1842, p. 550.
} 
concentration': 'A speech was presented at her grave by one of our brothers and ten days after her death, animated by the spirit of holy brotherhood, we went to her tomb to place a modest cross on which we had written the epitaph of her martyrdom. After having accomplished this holy ministry, in the presence of an innumerable crowd, four speeches were made in the midst of a deep sadness. A self-censorship had been established so that no speech which she would not have approved, was presented.' Certainly, they demonstrated how belonging to their community transformed into a contest of conformity; but it also displayed a great friendly piety and a conviviality based on the idea of civil virtues, cultivated almost ostentatiously.

Pépin was an artisan making mirrors in Périgueux. On November 11, 1843, he wrote to Cabet: 'Sir, in the short time that I have possessed Travels in Icaria, I have found such beautiful things that I believe it can only be the work of a divine being who inspired you.' ${ }^{16}$. He asked to subscribe to Populaire and for Cabet to send him two portraits of himself. The latter replied immediately: 'I always feel a movement of happiness when I discover an intelligent and generous man who shares my feelings and my doctrines.' 17. Pépin became Populaire's correspondent for the region of Dordogne. In 1846, there were more than fifty newspaper subscribers in the city of Périgueux alone ${ }^{18}$. He seemed to be one of the first to have advised on the emigration of Icarian communists ${ }^{19}$. In May 1847, when reading the call to found Icaria in America, he exclaimed: 'We have gleefully welcomed your Great Confidence, like a cry of salvation thrown in the midst of the social sinking in which we're threatened to be swallowed up.'20. 'How happy I am,' he exclaimed again, 'to see you having stood for what I have never ceased to think of. Yes, let's abandon this worm-eaten and gangrenous society as soon as we can! Apostles of social regeneration will lay the first stone of the building announced by Christ. Honoured will be the first founders of it. (...) I am impatient to see the happiest day of my life, the day I will set foot on the boat that will transport us; for we will leave the life of the tombs to be born in the promised land and under the enlightening sun.' ${ }^{21}$ Pépin was in charge of organising a departure of Icarian migrants for the United States from Bordeaux. On October 21, 1848, a correspondent of the Démocratie pacifique testified: 'Tuesday morning, towards 10 o'clock, the boarding of Icarians took place in Bordeaux. They were about sixty in number, accompanied by fifteen to twenty women and several children. While walking in procession and in the greatest silence, they have reached the cold bay, where a galley and a small boat

\footnotetext{
16 Bibliothèque Nationale de France, Papiers Cabet, Nouvelles Acquisitions Françaises, folder 18148, folio 133, letter dated 11 November 1843.

${ }_{17}$ BNF, ibid., folio 134, copy of letter dated 15 November 1843.

18 Populaire, 28 August 1846

${ }_{19}$ BNF, op. cit, folio 164, copy of the letter of Cabet to Pépin dated 6 April 1847. Cabet asks for discretion and silence; folio 165, Cabet announces him, in advance of his decision about departure.

20 Populaire, 11 July 1847.

${ }^{21}$ Réalisation de la Communauté d'Icarie, n, May 1847, p. 47, “On nous écrit de Périgueux" ['Written to us from Périgueux"].
} 
furnished with several pavilions awaited them. (...) Then one of the leaders, turning towards the crowd that such a spectacle naturally had to draw to the banks of the river, uttered: 'We are voluntary exiles who go, under the guard of God, for the conquest of Liberty.'. His little harangue was followed by cries: 'Long live the Communists! Long live Icarians! Long live Cabet! Long live the Social Republic! (...)' We have generally noticed the behaviour of these migrants, who appear to be honest workers and good fathers of their families. Their broadbrimmed white chapeaux and black velvet cloaks were quite picturesque. The women all wore straw hats encircled with blue ribbons; they were generally very young and very pretty." 22 The Cabot, the ship on which Pépin had embarked, arrived in New Orleans on December 17, 1848, two months after its departure from Bordeaux. Pépin, confronted with the hardships of communal life since embarking, and disappointed by the failure of the first avant-garde in Texas, quickly decided to abandon the cause of the founders of Icaria and asked for immediate repayment of his contribution to the American community so that he could return to France. Having become a dissident, he was no longer an Icarian. We can also exclude ourselves from the community, freely.

\section{Tests and trials: forming a group through times of pain}

Experiencing community life not only induced a strong sense of belonging and a foundation for communal identity, but also uncovered the presence of a difference, a third party appearing under and beyond its original outline. The most painful experience of otherness and limitation came from within the Icarian group. Tensions and variances among the members haunted their community, driven by actual as well as by spectral divisions. Moments of harmony, agreement and perfect balance were rare, if at all present. Inventing new forms of social bonding while incessantly struggling to avoid conflict was impossible. The history of the readers of Populaire was marked by these moments of crises where everyone had to choose his camp, decide to stay or leave, persevere or enter into dissidence.

In October 1842, Cabet published a rough communication under the title Useful and frank explanation of practical questions for the communists from Lyon ${ }^{23}$. What he provided was a polemic with his former secretary, Theodore Dézamy. The Lyon Correspondence Commission refused to distribute his last pamphlet and five workers wrote to him for explanation. He published their letter, in which he was accused of lacking cold blood and even dignity in attacking the author of Code de la Communauté, of being motivated in his writing by anger and hate: 'You understand that we cannot propagate the article in question. Our cause would suffer from this publication,

\footnotetext{
22 La Démocratie Pacifique, 21 October 1848.

23 The brochure has 29 pages in total.
} 
and with it would you. What would people whose convictions are still feeble say? How could they believe in fraternity when they see the preeminent apostles of this doctrine torn apart and throwing mud in each other's faces? Besides, our time is too precious for us who work much and earn little, to spend any part of it propagating or reading such texts, which serve only to multiply our divisions, already too numerous.' Cabet was particularly accused of excessive vanity and, implicitly, of aspiring to an abusive dominion over the communists: 'Be more sober also in the publication of letters where praise overflows, and which you produce against your adversaries as a glorification of your conduct. In short, stop spilling your ink and restrain yourself to the substantial articles really worthy of you! It is only at this price that we will use our zeal for the propagation of your works and that we will continue to pay you a tribute of recognition and fraternal esteem.' ${ }^{24}$. The letter, dated September 1842, is signed by Vincent, Ginaud, Perret, Greppo ${ }^{25}$ and Calendras. With some of the communists of Lyon, all that remained was a rupture. Such an observed attempt to dominate created a situation of crisis. The community of Icarian Communists was a living organism and without fixed rules of functioning its reconfiguration was permanent. Any attempt to seize power, to decide, stigmatize, weaken, isolate one or more members generated disruption, jolted the group to the point of separation and departure of the dissidents, definitive or provisional.

In May 1847, some time after he published his call to collectively emigrate to America, under the innocuous title Confidence, Cabet received a letter from twenty-eight communists from Nantes who did not agree with the unexpected and sudden announcement. According to them, it was an appeal to desert the cause of democracy in France at the worst moment, when the onset of an imminent revolution was expected. This discrepancy ended in a break up, repeating the situation with the workers of Lyon five years earlier. The only possible outcome of discussions, disagreements or quarrels between the Icarians was separation, exit, exclusion from the community, the branding of those who disagree 'dissidents', followed by forced departure. With a similar intention Cabet published the letter of the Nantes protesters who wrote to him in July 1847: 'Progress advances at a great pace and if only his breath could have swept away the despots would the People kiss themselves with fraternity. Meanwhile, however, we believe in the obligation of every devoted soldier to stay in his position; to this effect, France as the centre of modern civilization, so devoted to the hatred of absolutist powers, in its very heart necessitates those who can and must to defend it!... As we see it, it is neither the hour nor the moment to abandon her; for never have the People and Liberty run any greater risks!' They

\footnotetext{
${ }^{24}$ Quotations intervowen in commentary of Cabet, p. 7-19.

${ }^{25}$ Louis Greppo, deputy in 1848 and in 1871 . He will hold his seat amid the benches of the extreme left until 1885.
} 
added: 'In the interest of the cause we defend, please make this protest public in the next issue of the Populaire.' ${ }^{26}$

Cabet replied to them: 'The most influential have been deceived and entailed by manoeuvres and calumnies about which we know only as much as we can guess: they have been made to believe that the Community was possible in France, and that an approaching revolution would establish it there.'. This explanation was common: it was the access of the revolutionary communists to the community of his readers that caused all the evil; they were the dividers, they fomented discord and incited misunderstanding. In response to the twentyeight protesters he cited the address of two hundred faithful habitants of Nantes, forty-five of which were women, who exclaimed: 'The news of your Emigration project has excited such enthusiasm in our city that it is impossible to describe. ${ }^{27}$

There was one more correspondent, this time from the outskirts of Paris, who also wrote to him about the departure plans: 'Lightning already cleaves the space; the storm is ready to burst over our heads; the waves roar in the distance; must it be that in the face of the unchained winds, of this frightful torrent which can drown the vessel of humanity, its best pilots have to abandon it?'. ${ }^{28}$ 'The doubt seemed legitimate and did not take the form of an attack, permitting its interlocutor to explain himself in his answer, thus consolidating consensus and again tightening bonds. To his dissenters, Cabet presented hundreds of letters of support. They were all fuelled with the discomforting experience of animosity ${ }^{29}$. For example, seventeen correspondents from Le Havre wrote to him, still in 1847 in response to his dissenters: 'We cannot describe the satisfaction which your Confidence has brought us; for from now on we dream of Icaria, of this great, much desired day when we will see the sails of the ships taking us to this land free from all blemish; where we will lay the first stone of the great luminous lighthouse which must illuminate the whole of humanity'. 30

In these conditions, the community of readers of Populaire remained a device, a weapon to contest everything except itself. Within it, dissension was definitely not possible. However, seen from the outside, its nationwide scope, its destabilising effectiveness, the disorder it introduced into the social order, began to pose problems. From 1846, the highest authorities of the state and the main organs of the conservative press started to sound the alarm. On January 19, 1847, Gabriel Delessert, the prefect of the Paris Police, wrote his report to the Minister of the Internal Affairs regarding a number of books published in 1846 which he had just read. He quoted Cabet's Populaire and his Vrai Christianisme suivant Jésus-Christ. He wrote to

\footnotetext{
26 Which was done in: Populaire, 4 July 1847 and also in the brochure Réalisation de la Communauté d'Icarie, $\mathrm{n}^{\circ} 2$, August 1847, p. 92-93.

27 Réalisation de la Communauté d'Tcarie, n², August 1847, p. 94.

28 Réalisation de la Communauté d'Tcarie, $\mathrm{n}^{\circ} 2$, August 1847, p. 56.

29 They are the main part of the content of the Réalisation de la Communauté d'Icarie, counting over 400 pages.

30 Réalisation de la Communauté d'Icarie, n² 2, August 1847, p. 63-64.
} 
the minister about the antisocial miscellanea which he had just viewed ${ }^{31}$ : 'All depict the working class as falling prey to anarchy and exploitation and seek to mislead it at once by the exaggerated picture of its miseries and by the portrayal of the happiness which those people would be called to enjoy as a result of social reconstruction. It is easy to understand all the appeal that such writings find among the easy and uneducated minds of working men, provided that they also flatter all their material appetites. This is the true plague of the time, and we have to take notice that each year it makes new progress'32. This was the time to complicate the task of social reformers. Cabet was attacked directly in 1847, accused of fraud over his emigration project. His disciples in all sectors of society found themselves subjected to the developing strategies of banning them from the public space and the arising problem of anti-communist hatred. They called it a situation of 'persecutions'.

In 1847, there were a hundred Icarians of Toulon who would show themselves proud, superb, consistent in the face of this adversity: 'The truth is not wearing a veil. We allow our persecutors to view our letters and our speeches to prove that we are not abusing the law, which is the basis of their accusations. Deeply penetrated by the justice of our position, we are not afraid to walk with confidence and lift our heads to show them our pure and radiant faces, which learned the truth that you have taught us. Eh! What should our persecutors fear if we want to establish our Doctrine only by the strength of public opinion. Wouldn't it collapse under scrutiny if it weren't the truth? Furthermore, what can they fear if we are to bring it about only on soil which doesn't belong to them? We are sure of you as the first apostles were sure of Christ, and your persecutions will only increase our zeal to spread the Holy Doctrine of the Community.' 33

The story of Richard, an entrepreneur in Villepreux, Seine-et-Oise (nowadays in Yvelines), is more tragic. It was also published in Populaire:

'I believe it my duty to acquaint you with a vast system of persecutions practiced against the communists in our country, especially against Richard, your correspondent, whom, as it seems, they want to ruin, and to whom much wrong has already been done. In our region the persecutions against communism date back to the last elections to the National Guard, where there were plans of appointing Richard, your correspondent, for a Battalion Commander. Since then, the rumours started to spread that the communists of the country and the neighbouring cantons form a secret society and hold secret gatherings of which he is the president. We are accused of raising the prices of grain and starting fires. (...) Those are the insults and libels on the part of the poor inhabitants of villages, abandoned in their ignorance or plunging into stupidity. "We should," they exclaim, "hang all the communists and all the priests, and if there

\footnotetext{
31 Precisely he says: miscellanea "attacking the society".

32 Text quoted in its entirety in: Garnier-Pagès 1868-1870, 156.

33 Cabet, Réalisation de la Communauté d'Tcarie, n 8, December 1847, p. 392.
} 
was a revolution, we would slaughter every last one.". This is how, in their eyes, the communists get along with the priests. Poor people! At the same time, they claim that we get along with the devil! The prefect sends circulars to the mayors of Villepreux and to the villages two leagues around, in which he warns that a Monsieur Richard, communist, hold rallies in the municipalities of Saint-Nom, Feucherolles, Crespières, Chavenay, Noisy, Rennes-Moulin, Fontenay-les-Clayes, Plaisir, Trappes, Château-Fort, etc., in order to excite the workers to revolt, by distributing and explaining the communist pamphlets. He encourages them to keep their eye on him and send their reports to the prefecture as soon as possible. You could not imagine the group formed against him to deprive his masonry services of its entire clientele, to take away his credit, to destroy him morally and commercially! He is watched, at his place and elsewhere, by the disguised, snitching gendarmes. Although he is a courageous and firm man, these molestations, vexations and obstacles that they enforce upon his affairs have made him ill, since I believe that this is exactly the main cause of his illness. (...) However, investigations continue; the gendarmes run through the villages at a gallop and chasing the communists they forget about the thieves and poachers; and even a special police commissioner, ancillary at the Palace of Versailles, went a long way up to our house. They spread a thousand frightening rumours, they say that Populaire and communist brochures were confiscated, that Richard, all the other correspondents of Populaire, and Mr. Cabet himself are in prison; it is also said that the communists hog the grain and set fires; there was also seen a peasant (from Flescamville), who has just escaped the fire and said that if he found a communist, he would kill him with his pitchfork" ${ }^{34}$. The rest of the story is reported by Cabet: "Richard, an entrepreneur from Villepreux, near Versailles, was one of the most recommendable Icarians, for the generosity of his character and his devotion to the cause of the people. (...) He was in bed, sick, tormented, when two gendarmes came knocking on his door to search his house and probably to arrest him as a communist. Finding the door closed and seeing the window of the ground floor open, they climbed this window to appear swiftly in front of the patient in bed. This sudden and violent entrance, which surprised him in an attack of fever, excited such a shakeout that he died the next day. (...) Nearly two hundred of his fellow citizens had the courage to come to honor his memory by accompanying him in a gloomy, pious silence to his last abode. ${ }^{35}$

These difficulties or rather the impossibility even to attempt to live in community, be it only a community of readers, under existing conditions and in a society which was becoming more and more violent, hostile, harshly intolerant, unable to bear those who try to live differently, forced Icarians to adopt Cabet's point of view: there was no way but to leave, and no place for the community of Icaria unless very far away, in the desert. To found a community,

\footnotetext{
34 Réalisation de la Communauté d'Icarie, n, May 1847, p. 17-18.

35 Populaire, Sunday 20 August 1848.
} 
real this time, they would have to reach the virgin lands of the new world, where anticommunist hostility did not exist, not yet.

\section{Conclusion}

In the introductions of numerous studies on nineteenth and twentieth century communes, their authors claim their foreordained failure. Community is a place, a way of fleeing from the real world ${ }^{36}$. It is a negation and cannot be more than an illusion. Therefore Cabet and his friends must have failed in their American experience. After fifty years of community life in Illinois and then Iowa, his followers had to dissolve Icaria. Yet considering the length of this period, speaking of 'failure' seems questionable. At times, in Nauvoo on the banks of the Mississippi, there were more than five hundred men, women and children included, who wanted to make an attempt at absolute democracy and perfect equality. The failure of this community, even if it was to happen, does not say anything about what it was or has been: a continual experimentation which, obviously, can fail.

In France, before their departure, Icarians had already experimented with communal functioning, but without really knowing it, without really foreseeing it, even if they had chosen a new name to distinguish themselves. Around Cabet, but also partly without him, they invented a new form of living together. They did not simply constitute the clientele of a newspaper, the receivers of a particular doctrine, the proselytes of a political and social utopia. They also contributed to the invention of a new form of social link: they were the ones who produced what was essential in Icarian writings while Cabet's role was to transmit their unceasing, inter-urban conversation, their informing each other of their joys and their disappointments. They displayed to each other their practice of communal faith; shared their aspirations and dreams; declared their unrestrained communist commitment; joined in their militant walks in the countryside on Sunday, their evening discussions in the workshops after work, their desire to learn. Their texts distinguished Populaire from its contemporary journals in the nature of relations maintained not only with but also between its readers: in the Démocratie Pacifique or during the conferences organized by the Fourierists, they exposed their doctrine,

\footnotetext{
36 See in particular: Lacroix 1981. Here already the first chapter is titled: "La cité communautaire: l'expérience d'un échec" ["Comunitarian city: the experience of failure"] (Lacroix 1981, 19). Regarding Icarians, see: Rude 1980. Author reprints here a diary of J.-F. Crétinon and F.-M. Lacour, two communists from Vienna who decided to join Icarie for a couple of weeks at its worst moment, when began a crisis provoqued by Cabet's eviction in 1856. F. Rude, followed by many readers for more than thirty-five years, ascribes the disappointment of his two travelers to the inevitable failure of the "great Icarian adventure" in America. In his introduction, 90 page long, he castigates the attempt of the Icarian community. On page 26, he does not hesitate to write: "Cabet is the precursor of contemporary totalitarian regimes". The disappointment of his disciples was, according to him, inevitable, even if he had studied only two out of several thousand, at least 5000, who tried and experienced it with much more perseverance.
} 
especially to a public of cultivated bourgeoisie, attentive to novelty; in Atelier, elite workers offered their fellow men a conscientious reflection on the social question, similar to the approach of Louis Blanc or Pierre Leroux in various journals in which they participated. Proudhon, in the Représentant du Peuple, then in Peuple and in Voix du Peuple tried to advance the social revolution (Bouchet et al, 2015) ${ }^{37}$. In Populaire, the philosophical content and the economic, social or political information, not belonging to the essence of the journal, were most often poor, almost deliberately so. What was always richest was the enthusiasm and happiness of Cabet's disciples for being able to show themselves, how they behaved and lived like Icarians.

\footnotetext{
37 See in particular, except for the ones already quoted, the contributions of B. Desmars about the Démocratie Pacifique or of Th. Bouchet on the Phalange, of Ph. Régnier on saint-simonian journals the Producteur and the Organisateur, of F. Jarrige and M. Lauricella on "experience" of the Atelier and of Ed. Castleton on proudhonian journals.
} 


\section{References}

Beecher, Jonathan. 2012. Victor Considerant. Grandeur et décadence du socialisme romantique. Dijon: les Presses du reel.

Bouchet, Thomas, Vincent Bourdeau, Edward Castleton, Ludovic Frobert and François Jarrige (eds.). 2015. Quand les socialistes inventaient l'avenir. 1825-1851. Paris: La Découverte.

Cabet, Étienne. 1841. Ma ligne droite pou le vrai chemin du salut pour le Peuple.

Clastres, Pierre. 1974. La société contre l'Etat. Paris: Editions de Minuit.

Fourn. Francois. 1998. Étienne Cabet (1788-1856). Une propagande républicaine. Vol. II. Villeneuve d'Asq: Presses du Septentrion.

Fourn, François. 1999. "Icariens et Phalanstériens. Regards croisés entre 1845 et 1849", Cabiers Charles Fourier, n 10, online: http://www.charlesfourier.fr/spip.php?article174 (access 25 July 2018).

Fourn, François. "Les brochures socialistes et communistes en France entre 1840 et 1844". Cabiers d'Histoire, revue d'bistoire critique, $\mathrm{n}^{\circ}$ 90-91, 2003: 69-83.

Fourn. Francois. 2014. Étienne Cabet ou le temps de l'utopie. Paris: Vendémiaire.

Fourn, François. 2015 “L'utopie ou la barbarie. Contre la violence révolutionnaire. Cabet et Le Populaire". In: Thomas Bouchet, Vincent Bourdeau, Edward Castleton, Ludovic Frobert et François Jarrige (eds.), Quand les socialistes inventaient l'avenir. 1825-1851. Paris: La Découverte.

Fourn, François. 2017, "La mode ne varie jamais en Icarie (1840-1898) ou comment s'habiller en communiste au XIXè siècle", Modes pratiques, revue d'bistoire du vêtement et de la mode, $\mathrm{n}^{\circ} 2$.

Garnier-Pagès, Louis-Antoine. 1868-1870. Histoire de la Révolution de 1848, vol. I. Paris: Bibliothèque libérale.

Johnson, Christopher H.. 1974. Utopian Communism in France: Cabet and the Icarians, 1839-1851. London; New York: Cornell University Press.

Lacroix, Bernard. 1974. "Le discours communautaire", Revue française de sciences politiques, n³: 526-558.

Lacroix, Bernard. 1981. L'utopie communautaire. Histoire sociale d'une révolte. Paris: PUF.

Maillard, Alain. 1999. La Communauté des Egaux. Le Communisme néo-babouvisme dans la France des années 1840. Paris: Kimé.

Maillard, Alain. 2015. Egalité et communauté, la presse communiste. L'Intelligence, le Moniteur républicain, l'Homme libre, l'Egalitaire, la Fraternité de 1841, "Travail, Humanitaire and Fraternite'. In: Thomas Bouchet, Vincent Bourdeau, Edward Castleton, Ludovic Frobert, Francois Jarrige (eds.), Quand les socialistes inventaient l'avenir. 1825-1851. Paris: La Découverte, p. 168-180.

Paris, Jean-Michel. 2014. L'Humanitaire (1841). Naissance d'une presse anarchiste?. Paris: L'Harmattan.

Proudhon, Pierre-Joseph. 1994. What is property? Ed. by Donald R. Kelley and Bonnie G. Smith. Cambridge: Cambridge University Press.

Robert, Vincent. 1999. “Géographie de l'utopie. Icariens et phalanstériens à la veille de 1848”, Cabiers Charles Fourier, 1999, $\mathrm{n}^{\circ}$ 10, online: http://www.charlesfourier.fr/spip.php?article175 (access 25 July 2018). 
Rude, Fernand. 1980. “Allons en Icarie!” Deux ouvriers isérois aux Etats-Unis en 1855. Grenoble: Presses universitaires de Grenoble.

Tönnies, Ferdinand. 2017. Community and society. London: Routledge.

Tristan, Flora. 1980. Le tour de France. État actuel de la classe ouvrière sous l'aspect moral, intellectuel et materiel. Paris: François Maspéro.

Valette, Jacques. 1981. “Utopies sociales et utopistes sociaux en France en 1848”. In: John Bartier, Jacques Valette, Société d'bistoire de la Révolution de1848 et des Révolutions au XIXè siècle, 1848. Les utopismes sociaux. Paris: Sedes. 
François Fourn - an associate professor in Lycée Victor Duruy, second degree, holds a PhD in history for his thesis on the political role played by Cabet in France in 1830 and 1840. He is also the author of a more biographical text, Étienne Cabet ou le temps de l'utopie. His research concentrates on utopian communism, as well as on anti-communism, different forms of socialism in the nineteenth century (Louis Blanc, Proudhon, the Fourierists) and French emigration to America.

\section{DANE ADRESOWE:}

Lycée Victor Duruy

33 boulevard des Invalides

75007 Paris

France

EMAIL: fournfrancois@gmail.com

Cytowanie: François, Fourn. 2018. „Icarian communism between 1841 and 1848: a community of readers" Praktyka Teoretyczna 3(29): 78-95.

DOI: $10.14746 /$ prt.2018.3.4

\section{AUTOR: François Fourn}

TYTUŁ: Komunizm ikaryjski w latach 1841-1848: wspólnota czytelników

AbstraKT: W 1842 roku czytelnicy Le Populaire, pisma utworzonego rok wcześniej przez Etienne’a Cabeta, nadali sobie miano ikaryjskich komunistów. Ale do czego się w ten sposób odnosili? Partia komunistyczna, szkoła nauk społecznych, sieć, ruch, sekta - wszystkie te słowa mogą wyrażać naturę więzi, które rozwinęły się pomiędzy nimi w latach 1841-1848. Proponuję jednak nazwać ich mianem wspólnoty czytelników. Wynaleźli oni bowiem nową formę bycia razem. Ikaryjscy komuniści nie byli jedynie czytelnikami, lecz również twórcami, adresującymi swe dzieła do innych członków wspólnoty. W ramach owej wspólnoty osoby te dzieliły się pieniędzmi, ale również podzielały wspólne, egalitarne poglądy, wiarę w braterstwo oraz wdzięczność, a wręcz oddanie Cabetowi. Członkostwo w ramach takiej społeczności, angażujące wszystkie sfery życia, było rozwijane i manifestowane w różnych formach. Pociągało ono za sobą również częstokroć bolesną lekcję o ograniczeniach wspólnoty, zarazem wewnętrznych i odnoszących się do całości francuskiego społeczeństwa, które z trudem akceptowało jej funkcjonowanie.

SŁOWA KLUCZOWE: czytelnicy czasopism, Francja, komunizm ikaryjski, rok 1848, socjalizm utopijny, wspólnota 